\title{
Strategic map as a tool for increasing the investment attractiveness of the regional construction sector: case of the Murmansk region
}

\author{
Aleksandr Kozlov ${ }^{1,2, *}$, Anna Teslya $^{1}$ and Ekaterina Tereshko ${ }^{1}$ \\ ${ }^{1}$ Peter the Great St. Petersburg Polytechnic University, Polytechnicheskaya, 29, St. Petersburg, \\ 195251, Russia \\ ${ }^{2}$ University of Economy in Bydgoszcz, Bydgoszcz, Poland, Garbary,2, Bydgoszcz, 85-229, Poland
}

\begin{abstract}
A review of studies found that investments in construction have a multiple macroeconomic effect; therefore, these flows must be stimulated. However the study revealed that investments in construction in the Far North regions of Russian Federation including Murmansk region have suffered a decrease over a 20-year period, which has a negative impact on the infrastructure and the logistic system. Thus the goal of the research was to develop a strategic map for the sector's development in order to increase its investment attractiveness. The paper suggests improving the investment attractiveness on the basis of the concept of a set of regional indicators, which is easily visualized by strategic maps. The proposed strategic map for construction sector of Murmansk region consists of four components: training, development and innovation; industry and entrepreneurship; society and market; regional finances and contains the key indicators characterizing each of the components. These components and corresponding indicators allow for regional authorities formulating the strategy of the sector development and monitoring the results of the strategy implementation.
\end{abstract}

\section{Introduction}

Analysis of current trends in the political and economic development in the context of globalization confirms that the competition for leadership between countries has been intensifying. One of the key factors in this competition is integrated development of regions with high potential for economic growth. This competition is quite strong in the regions of the Arctic Circle, since the Arctic is a promising site with large territories belonging to countries rich in raw materials and unique human resources. For this reason, choosing the correct vector of development of the Arctic is the key to success in this competition.

An evolved infrastructure is the critical factor for providing the essential services and ensuring the successful functioning of the Arctic; this should be borne in mind in determining the key component of the development of these territories. Infrastructure objects include road

\footnotetext{
*Corresponding author: avk55-spb@yandex.ru
} 
building and maintenance, housing construction, social care facilities, and cultural institutions. All these elements of the infrastructure are created through the regional construction sector; improving it will provide an opportunity to expand the logistics system, increase the potential of business associations, develop social and cultural institution, and promote the integrated development of mineral raw materials. Investment flows coming from both private sources and the public sector lay the foundations for the development of the construction industry. Investments stimulate the development of the industry, while the analysis of the flows allows assessing the level of development of a particular territory relative to the construction sector, which acts as a driver of regional development.

The Arctic zone of the Russian Federation [1] makes up 50.59\% of the entire territory of the country [2]. The Far North of Russia includes according to [3] even more territories of Russian Arctic. Each territory of Arctic has its own peculiarities of development and internal functioning; for this reason, a specific object should be chosen for consideration. The Murmansk region, which has access to the Northern Sea Route and is rich in mineral resources [4], plays a special role in the Arctic. The functioning of the region's infrastructure facilities is at an average level, which was established by analysis of the data collected by the Federal State Statistics Service [2]. This is why the city of Murmansk and the Murmansk Region were chosen as the object of research.

A considerable number of studies are dedicated to this subject, discussing the experience of different regions of the Russian Federation in the development of the construction sector, the experience of foreign countries, as well as a variety of methods used for assessing investments, understanding the relationships with the key economic indicators. Great contributions to the study of the mutual influence of investment flow in the construction sector and economic growth of different territories were made by Russian and foreign researchers such as Kozonogova, Yolokhova, Kataeva, Persky, Gubaidullina, Vatin, Teslya, Cherepovitsin, Hong, and others.

A number of studies [5-13] discuss the overall macroeconomic impact of investment in housing construction in the entire Russian Federation as well as in its specific territories. Yolokhova and Kozonogov [5] established the mutual influence of the key economic indicators of the Russian regions on investment flows through mathematical evaluation of the mutual influence by correlation analysis of the indicators. Studies prove that investments in housing construction of a region are closely linked to the key indicators of the region's performance.

The paper [6] describes the Volga Federal District, emphasizing the construction of a model of "Multiplicative effect of a segment of housing construction on the economic development of the region". Local authorities can use this model to determine the amount of investments in housing required for covering the population's need for housing in a specific region. Hananaev, Kovalenko and Zaikina [7] presented an effective system for assessing the financial and economic performance of construction companies of the Krasnodar Krai, based on methods of multivariate statistical analysis. Gubaidullina and Kozonogov [8] discuss the investment attractiveness of the housing market in the Russian Federation, finding that a time-dependent model had to be constructed to determine the effect of investments in the construction sector on the investment attractiveness of a region, as well as the corresponding generalizing (multiplicative) effect. According to the authors, the development of the housing construction market should be the key driver increasing the investment attractiveness of a region. The environmental aspect of the technologies used in construction as a factor of investment attractiveness was considered in [9]. Nidziy [10] touches upon the problem of economic crisis and its impact on the main performance indicators of the Russian construction sector. Ref. [11] presents an assessment of the characteristic indicators that can be used to estimate the economic growth and sustainable development of the construction industry with St. Petersburg described as an example. Ref. [12] offers to improve the 
organizational structures of construction companies based on modeling as a solution to the problem of increasing investment attractiveness. The article [13] considers the value-based management of construction companies as the key factor in investment attractiveness of the construction industry.

The studies [14-16] analyzed the foreign experience of increasing the investment attractiveness of the construction industry. Ref. [14] studied the investment potential of the construction industry in Montenegro, regarding an open market as a factor attracting an influx of foreign investments into the sector. The importance of management skills and knowledge oriented at the middle management personnel was established for cooperation with foreign investors, which indicates that the first steps towards international competitiveness have been made.

Some studies, for example, [15], discuss Chinese regions and are interesting and significant for generalizing the international experience. Hong evaluated the dynamic relationship between investments into real estate and economic growth based on the data from 284 Chinese cities for the period from 1994 to 2010. The author believes that the positive effect of investments in real estate has a stronger impact on economic growth in the short term and will turn negative in the long term. Therefore, investments in the construction sector are an important factor for short-term economic fluctuations.

Fokina [16] reported the mutual influence of investment flows and key economic indicators with respect to the boundary principle, comparing the regions of different countries. The paper considered possible ways of socio-economic development of Russia using the synergetic scenario method. Analyzing the experience of the USA and the USSR regarding $\mathrm{R} \& \mathrm{D}$ in the economy as a whole and in construction as one of the most important branches of the national economy, the author proved that a new industrialization has to be started in Russia in the conditions of the market and the information era. The paper also analyzed alternative scenarios for changing the Russian construction industry.

These above-mentioned studies have made serious contributions to developing methods for analyzing investment activity in the construction industry of different regions and countries, since they contain a considerable number of methods for analyzing the investment attractiveness of the industry in question. Nevertheless, the issue of investment attractiveness of investments in the development of the construction sector is currently still relevant because a large number of issues and regions, for example, the Far North of the Russian Federation, remain unexplored in this aspect, while all sectors of the economy are experiencing fairly rapid growth in these regions, and, as discussed above, the development of the regional construction sector is the crucial factor in regional development.

Thus, the goal of the study is to analyze the investments in the construction sector of the Arctic region, and to generate a strategic map for the sector's development in order to increase its investment attractiveness.

The object of the study is the city of Murmansk and the Murmansk Region.

The subject of the study is the regional construction sector in a broad sense.

\section{Methodology}

Quantitative and qualitative methods served as a methodological basis of the study:

1) Quantitative methods. These methods include collection and processing of statistical data, in this case, the socio-economic indicators of investments in the construction sector of the Murmansk Region. Quantitative methods include a conceptual model of a set of regional performance indicators (SRPI) using strategic maps with quantitative indicators recorded by the Federal State Statistics Service [17]. 
2) Qualitative methods. These methods involve transforming a balanced scorecard system into a system of regional performance indicators of the Arctic regions using the analogy method, analysis and synthesis, content analysis, cascading.

Thus, in accordance with the methodology, the stages of the study have been carried out in the following order.

1. Analyzing the statistical data reflecting the dynamics of investment flows aimed at the development of the regional construction sector.

2. Proposing a tool for managing the investment attractiveness of the region.

3. Choosing the indicators characterizing the dynamics of the development of the construction sector and reflecting the investment attractiveness of the industry.

4. Devising a strategic map for the development of the construction sector in the Murmansk Region

\section{Results}

Analysis of statistical data [2] reflecting the investments in the construction sector of the Murmansk Region was carried out over a 20-year period (from 1996 to 2015). We should note that up to 2005, the Federal State Statistics Service estimated the investment flows in specific industries as a percentage of the total volume of investments in the region, which was the most correct method, since it was thus possible to estimate the amount of investments received by a branch of the national economy. Since 2005, statistical data on the distribution of investments by industry are presented in monetary terms (mln RUB), which does not reflect the overall picture of the flows. In view of this, we have calculated the increment of investments in the construction industry relative to the total investment flow of the Murmansk Region starting from 2005 in order to determine the percentage of investments in the industry under consideration. Consequently, the trend of investment flows is shown in Fig. 1.

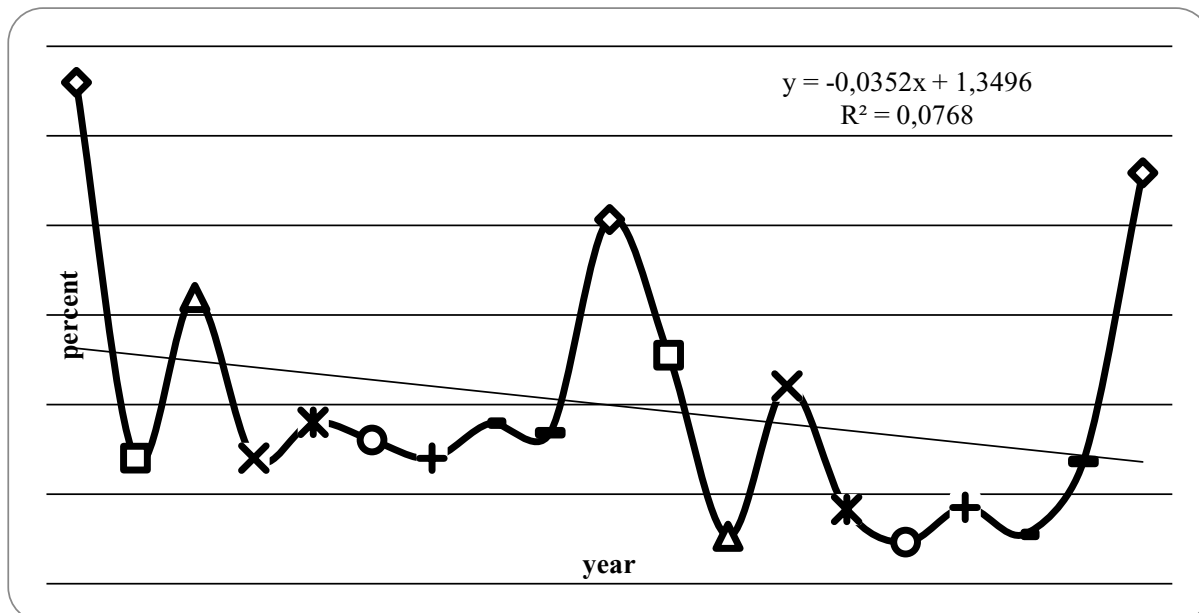

Fig. 1. Investments in the fixed capital of the Murmansk Region by type of economic activity (construction), 1996-2015.

Based on the trend revealed for investment flows in the construction sector, we can conclude that investment flows for maintenance, modernization and development of the construction sector are decreasing from year to year. This situation may be due to the specifics of the Arctic regions, which have the following problems: 1) severe climate; 2) insufficiently developed regional infrastructure; 3) limited economic prospects; 4) outflow of population. 
However, the Arctic regions have the following advantages: 1) vast territories rich in diverse natural and biological resources; 2) unique mineral and raw materials; 3) unique human capital, a combination of highly skilled human resources in industrial centers with indigenous small-numbered peoples. We should note that the program adopted for the development of the Arctic contributed to an almost triple increase in investments into fixed assets of the construction sector in 2016, but the share still remains extremely low (2.2\%). Consequently, finding mechanisms for increasing the investment attractiveness of the construction sector is a promising idea, since it is the well-developed construction sector in the Arctic region of the Russian Federation that can improve the infrastructure and increase the economic importance of the territories.

There are different approaches to managing the development of the regional investment attractiveness. A strategically viable decision-making system, aimed at potential investors who can be public authorities (as the main flow of investments to the region), as well as private investors such as entrepreneurs and shareholders, has to be developed in the Arctic. The public sector is the main source of financing, since it spends funds on basic social goods and services even in periods of economic recession, which private investors, facing high risks during these periods, may not be able to afford.

Consequently, a well-structured strategic development plan has to be devised for involving public authorities in solving problems of the Arctic regions. Any strategic initiative should be supported by a model and be practically feasible. The SRPI meets these requirements as a modified model of the balanced scorecard (BSC) system, adapted to regional specifics. This modified model was proposed and developed in $[17,18]$, it is the basis for decision-making and can be adjusted at any stage of implementation. The BSC system is also used in [19] as a structure for developing entrepreneurship in a region taking into account both internal and external factors.

SRPI includes four components: training, development and innovation; industry and entrepreneurship; society and market; regional finances. The model can be visualized in the form of a strategic map containing the key components in accordance with the adopted goals.

The advantages of this model are the integrity of the direction in managing the development of a specific subject; systematic data collection; the possibility of using the data provided by the Federal State Statistics Service; the development of specific indicators for monitoring each sub-goal in the component.

Choosing the priorities for the development of the construction sector of the Murmansk Region, we should note that the population of the region is declining despite the positive trends of certain indicators of socio-economic development (Table 1).

Table 1. Dynamics of some socio-economic indicators of the Murmansk Region, \% relative to 2012.

\begin{tabular}{|l|l|l|l|l|l|}
\hline Indicators / Period & 2012 & 2013 & 2014 & 2015 & 2016 \\
\hline Population (at the end of the year) & $100,0 \%$ & $98,8 \%$ & $98,2 \%$ & $97,7 \%$ & $97,1 \%$ \\
\hline Consolidated budget revenues & $100,0 \%$ & $105,9 \%$ & $108,7 \%$ & $125,4 \%$ & $136,9 \%$ \\
\hline $\begin{array}{l}\text { Gross regional product at current } \\
\text { basic prices }\end{array}$ & $100,0 \%$ & $108,0 \%$ & $115,7 \%$ & $137,6 \%$ & - \\
\hline Investments in fixed assets & $100,0 \%$ & $97,4 \%$ & $118,5 \%$ & $138,6 \%$ & $139,5 \%$ \\
\hline $\begin{array}{l}\text { The amount of work performed by } \\
\text { type of economic activity } \\
\text { "Construction" }\end{array}$ & $100,0 \%$ & $102,3 \%$ & $128,3 \%$ & $151,2 \%$ & $142,8 \%$ \\
\hline
\end{tabular}

The increase in investments into fixed assets and the amount of construction works carried out in the Murmansk Region is also confirmed by the dynamics of natural indicators (Table 2 ). However, it should be noted that growth is mostly observed in housing construction, while the share of industrial buildings decreased sharply compared with 2014. 
Table 2. Buildings opened in 2014-2016, \%.

\begin{tabular}{|l|l|l|l|l|l|l|l|l|l|}
\hline \multirow{2}{*}{$\begin{array}{l}\text { Indicators / } \\
\text { Period }\end{array}$} & \multicolumn{3}{|l|}{$\begin{array}{l}\text { Number of } \\
\text { buildings, units }\end{array}$} & \multicolumn{4}{|c|}{$\begin{array}{l}\text { Total building volume, } \\
\text { thousand cubic meters. }\end{array}$} & \multicolumn{3}{l|}{$\begin{array}{l}\text { Total area, thousand } \\
\text { square meters. m }\end{array}$} \\
\cline { 2 - 10 } & 2014 & 2015 & 2016 & 2014 & 2015 & 2016 & 2014 & 2015 & 2016 \\
\hline Total & $\mathbf{1 6 9}$ & $\mathbf{1 7 5}$ & $\mathbf{2 1 3}$ & $\mathbf{1 0 4 3 , 9}$ & $\mathbf{1 1 8 1 , 2}$ & $\mathbf{7 3 2 , 9}$ & $\mathbf{1 2 8 , 9}$ & $\mathbf{1 9 0 , 1}$ & $\mathbf{1 4 8 , 0}$ \\
\hline $\begin{array}{l}\text { Share of } \\
\text { residential } \\
\text { buildings, } \\
\%\end{array}$ & $36 \%$ & $42 \%$ & $50 \%$ & $12 \%$ & $20 \%$ & $41 \%$ & $23 \%$ & $23 \%$ & $53 \%$ \\
\hline $\begin{array}{l}\text { Share of } \\
\text { non- } \\
\text { residential } \\
\text { buildings, } \\
\%\end{array}$ & $64 \%$ & $58 \%$ & $50 \%$ & $88 \%$ & $80 \%$ & $59 \%$ & $77 \%$ & $77 \%$ & $47 \%$ \\
\hline $\begin{array}{l}\text { at. } \\
\text { including } \\
\text { industrial } \\
\text { buildings, } \\
\%\end{array}$ & $22 \%$ & $6 \%$ & $1 \%$ & $68 \%$ & $3 \%$ & $3 \%$ & $41 \%$ & $2 \%$ & $2 \%$ \\
\hline
\end{tabular}

The construction sector cannot be properly developed without considerable long-term investments. Analyzing the structure of sources of investment financing in the Murmansk Region, we should note (Table 3) that the share of borrowed funds decreased, while the share of public funding (primarily from the federal budget) increased. This indirectly indicates that investment attractiveness of the region is low.

Table 3. Structure of investments in fixed assets.

\begin{tabular}{|l|c|c|c|c|c|}
\hline \multicolumn{1}{|c|}{ Indicators / Period } & 2012 & 2013 & 2014 & 2015 & 2016 \\
\hline Total & 100 & 100 & 100 & 100 & 100 \\
\hline own funds & 41,5 & 44,3 & 44,1 & 43,4 & 46,9 \\
\hline involved funds & 58,5 & 55,7 & 55,9 & 56,6 & 53,1 \\
\hline at. t.ch. budget resources & 19,2 & 25,9 & 33,5 & 40,1 & 41,4 \\
\hline at. t.ch. federal budget & 15,5 & 20 & 29,5 & 37,5 & 39,1 \\
\hline
\end{tabular}

Analyzing the structure of investments in fixed assets (Table 4), we note a decrease in the share of long-term investments (except for investments in housing construction).

Table 4. Structure of investments in fixed assets by type of fixed assets as a percentage of the total.

\begin{tabular}{|l|l|l|l|l|l|}
\hline Indicators / Period & 2012 & 2013 & 2014 & 2015 & 2016 \\
\hline Total & $\mathbf{1 0 0}$ & $\mathbf{1 0 0}$ & $\mathbf{1 0 0}$ & $\mathbf{1 0 0}$ & $\mathbf{1 0 0}$ \\
\hline residential buildings & 1,4 & 1,4 & 1,6 & 1,7 & 6 \\
\hline buildings (except residential) & 40,6 & 37,8 & 37,4 & 34,4 & 30,8 \\
\hline $\begin{array}{l}\text { machinery, equipment, vehicles, production } \\
\text { and household equipment }\end{array}$ & 57,1 & 59,7 & 56,6 & 47,2 & 60,8 \\
\hline other & 0,8 & 1,1 & 4,4 & 16,7 & 2,4 \\
\hline
\end{tabular}

The result of the study and the generalization of statistical data is the conclusion that the development of the construction sector of the Murmansk Region requires a clear wellthought-out system of measures, reflected in the proposed strategic map (Fig. 2). The strategic map includes four components: training, development and innovation; industry and entrepreneurship; society and market; regional finances and contains the key indicators characterizing each of the components. 
Formation of a single construction complex of the Arctic region

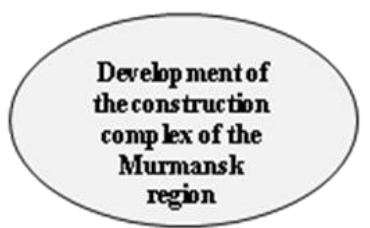

Specificity of development of individual teritories of the Arctic region

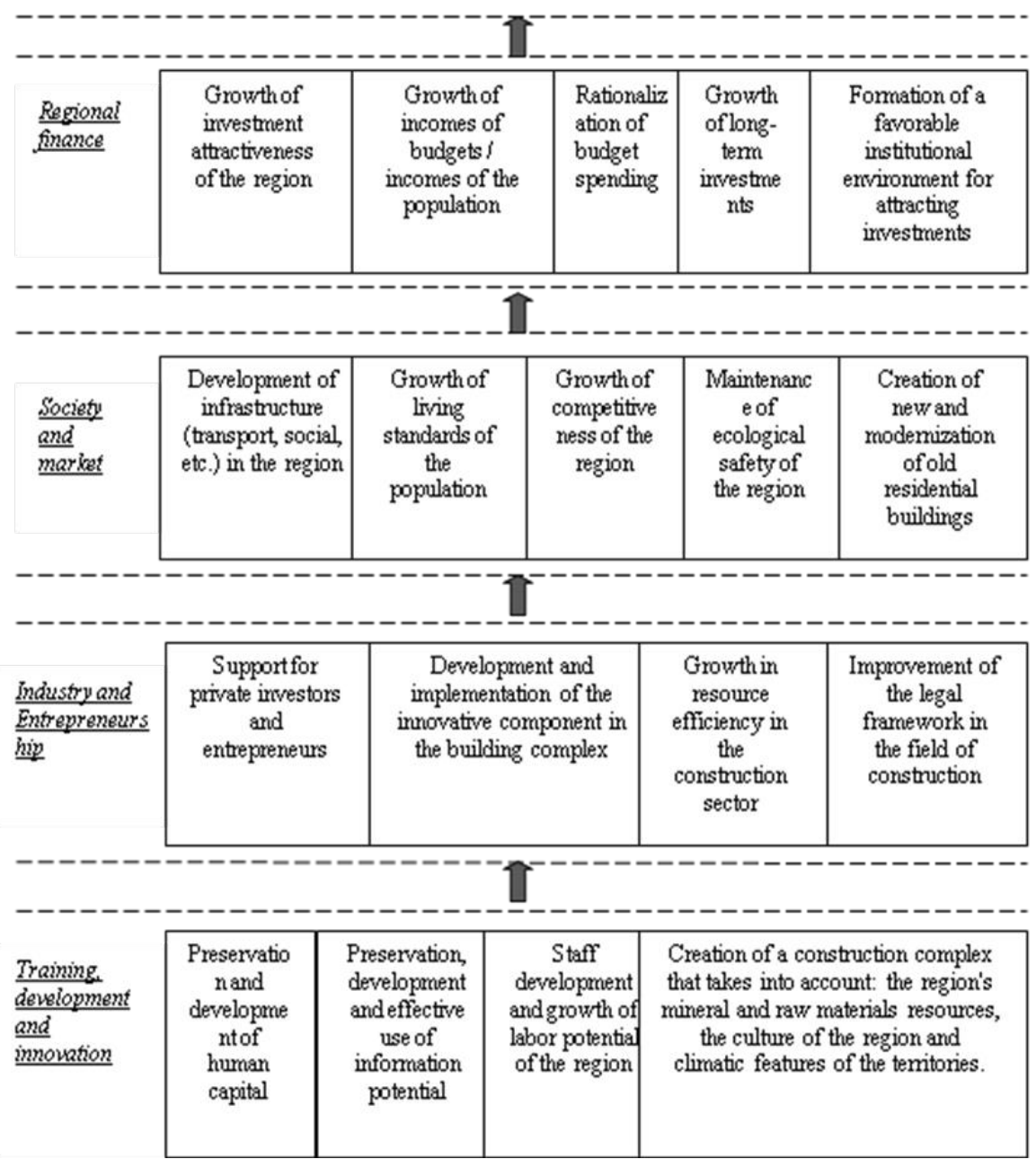

Fig. 2. Strategic map of the development of the construction sector in the Murmansk Region 
Thus, the proposed strategic map for the development of the construction sector of the Murmansk Region is a versatile tool for describing the development program, allowing to adjust the goals and the corresponding indicators, and to manage the process of achieving these goals. The strategic map devised for the development of the construction sector in the Murmansk Region makes up a part of the overall strategic map for the development of the region and is linked to other elements of the overall map [17].

\section{Discussion}

Notably, the development of the construction sector of the Murmansk Region generates an indirect social effect in addition to the economic one, as direct investments into the development of the construction sector induce an additional increase in investments in other sectors of the economy both in the region where the project is implemented and in the Arctic as a whole. The indirect social effect of investments in the development of the construction sector is due to reinvestment of the profits gained, contributing to an increase in personal and household income, an increase in domestic consumer demand, which is an additional factor contributing to the economic development of the Arctic regions.

Funds should have clear distribution routes at regional and municipal levels; forming a strategic initiative using the RPI, with the indicators visualized via a strategic map, makes it possible to correctly highlight the key points and not only launch a mechanism for the development of the construction sector in the Arctic regions but also to control this process.

\section{Conclusions}

We have carried out a brief review of scientific publications (in Russian and in English) in order to determine the trends in investment flows in the construction sector. The results obtained allowed to draw a number of conclusions on the dynamics of investment flows. Analyzing the studies on investment activity in the Russian Federation, we have established that a number of serious studies have been conducted for different regions and there are proposals for improving the structure of investments. However, no proposals have been found as yet for creating an integrated system for supporting investment flows in the construction sector of the Arctic regions.

The study was carried on investment flows in construction on the territory of a given research object in the Murmansk Region revealed negative trends over a 20-year period, which is confirmed by a downward linear trend indicator. The tool we have proposed for managing the process of stimulating investment activities is a set of regional performance indicators using strategic maps as a means of visualizing the development plan. The indicators include four components: training, development and innovation; industry and entrepreneurship; society and market; regional finances. We have proposed the key indicators characterizing each of the components of the strategic map. Thus, the strategic map we have devised for the development of the construction sector of the Murmansk Region allows to build a comprehensive model of the RPI, containing specific quantitative indicators of achieving the targets set for the development in accordance with the main goal.

Drawing up strategic maps for all levels of the Murmansk Region, including municipal authorities and individual businesses, is another possible direction for further research.

\section{Acknowledgements}

The paper is elaborated in framework of scientific project №16-32-00040 supported by Russian Foundation for Humanities. 


\section{References}

1. Decree of the President of the Russian Federation of 02.05.2014 N 296 "On land territories of the Arctic zone of the Russian Federation" http://www.consultant.ru/document/cons_doc_LAW_162553/(2017)

2. Regions of Russia. Socio-economic indicators http://www.gks.ru/bgd/regl/b16_14p/Main.htm (2017)

3. Resolution of Council of Soviet Union \# 12 of 03.01.1983 (Edited 27.02.2018 by Resolution of Government of Russian Federation) http://www.consultant.ru/cons/cgi/online.cgi?req=doc\&base $=$ LAW\&n=292097\&fld=1 $34 \& \mathrm{dst}=100001,0 \& \mathrm{rnd}=0.9873141117143966 \# 03503870717923685$ (2018)

4. A.M. Fadeev, A.E. Cherepovitsyn, F.D. Larichkin, Regional economy and management: electronic scientific journal 1(21), 0067 (2010) http://region.mcnip.ru

5. I.V. Yolokhova, E.V. Kozonogova, Fundamental research 11-4, 788-792 (2015)

6. Yu.V. Kataeva, Yu.K. Persky, Izvestiya Ural State University of Economic 3(25), 101108 (2009)

7. A.G. Hananaev, A.V. Kovalenko, L.N. Zaikina, Polythematic Online Scientific Journal of Kuban State Agrarian University 70, 207-220 (2011)

8. R.V. Gubaidullina, E.V. Kozonogova, Economics and business: theory and practice 7, 24-28 (2015)

9. G. Peshkova, A. Cherepovitsyn, P. Tcvetkov, Journal of Ecological Engineering 17(4), 17-24 (2016)

10. E.N. Nidziy, Vestnik MGSU 5, 119-129 (2016)

11. A. Teslya, A. Cherepovitsyn, E. Vyboldina, S. Fedoseev, S. Kozmenko, MATEC Web of Conferences 53, 01005 (2016)

12. I.V. Ilin, O.V. Kalinina, A.I. Levina, O.Yu., Iliashenko, MATEC Web of Conferences, IPICSE 2016, 05028 (2016)

13. A.R. Bril, O.V. Kalinina, I.V. Ilin, MATEC Web of Conferences 106, 08010 (2017)

14. S. Rutešić, J. Ćetković, M. Knežević, M. Žarković, N. Vatin, Procedia Engineering 117, 637-645 (2015)

15. L. Hong, IERI Procedia 7, 2-7 (2014)

16. Z.T. Fokina, Vestnik MGSU 5, 122-132 (2015)

17. A. Kozlov, S. Gutman, I. Zaychenko, E. Rytova, P. Nijinskaya, IOP Conference Series: Materials Science and Engineering 91(1), 012073 (2015)

18. E.V. Rytova, A.V. Kozlov, S.S. Gutman, I.M. Zaychenko, Journal of Advanced Research in Law and Economics 7(7), 1828-1836 (2016)

19. N.N. Kireev, Regional economy and management: electronic scientific journal 2(26), 0088 (2011) http://region.mcnip.ru 